\title{
Polypyrimidine Tract-Binding Protein 3
}

National Cancer Institute

\section{Source}

National Cancer Institute. Polypyrimidine Tract-Binding Protein 3. NCI Thesaurus. Code C114438.

Polypyrimidine tract-binding protein 3 (552 aa, $60 \mathrm{kDa}$ ) is encoded by the human PT BP3 gene. This protein plays a role in both erythropoiesis and RNA splicing. 